\author{
Ю. Тюріна, \\ аспірантка \\ Донецького національного університету імені Василя Стуса
}

\title{
СТАНОВЛЕННЯ Й РОЗВИТОК ЗАКОНОДАВСТВА ЩОДО ПРОДАЖУ МАЙНА БАНКРУТА
}

Продаж майна банкрута є основним способом задоволення вимог кредиторів. Чинний в Україні порядок продажу майна банкрута можна характеризувати залежно від способів, суб’єктного складу, строків, порядку продажу тощо. Сучасного вигляду порядок продажу майна банкрута набув нещодавно й отримав закріплення в Кодексі Украіни із процедур банкрутства, який уведено в дію 21 жовтня 2019 р. Варто зазначити, що чинний порядок продажу майна банкрута дещо відрізняється від попереднього, закріпленого Законом України «Про відновлення платоспроможності боржника або визнання його банкрутом». Це викликає зацікавлення питанням становлення й розвитку законодавства щодо продажу майна банкрута.

Питання історичної появи та розвитку інституту банкрутства досліджували О.М. Бірюков, А.В. Володін, В.С. Гордієнко, В.В. Джунь, К.М. Малишев, Б.М. Поляков, Г.Ф. Шершеневич та інші, які у своїх роботах торкались деяких аспектів продажу майна банкрута. Окремої уваги заслуговує дослідження О.О. Яковлева [1, с. 141]. Проте самостійного аналізу питання розвитку законодавства щодо порядку продажу майна банкрута не проводилось.

Викладене підтверджує актуальність обраної теми дослідження, метою якого виступає виділення етапів становлення й розвитку законодавства щодо продажу майна банкрута 3 конкретизацією особливостей такого порядку на кожному етапі. Це дозволить краще зрозуміти сутність сучасного порядку продажу майна, його сильні та слабкі сторони.

Аналізуючи наукову літературу, можна узагальнити, що перші унормовані згадки про банкрутство містяться в Руській Правді. Із посиланням на інших авторів О.О. Яковлев так описує все, що належить до цієї процедури: «Судових органів не було, судові функції виконували «владці», а суддями були князі, посадники та інші. Про князя як суддю Руська Правда згадує досить часто. Без княжого слова заборонялось карати на смерть та «огнищанина». У разі конкуренціï вимог кредиторів унаслідок неоплатності боржника предметом стягнення ставало саме майно боржника, а в деяких випадках - він сам. Тобто стягнення кредиторів було звернене на особистість боржника. Боржник підлягав продажу, а отримані кошти розподілялись між кредиторами за встановленою черговістю: іноземці, іногородні та інші кредитори. Однак борг князя оплачувався позачергово». Також О.О. Яковлев із посиланням на M.C. Грушевського звертає увагу на те, що кредитори мали право продати не тільки майно, але й самого неплатоспроможного боржника [1, с. 142].

На підставі аналізу положень Руської правди дослідники виділяють два види неплатоспроможності

1) необережне банкрутство, тобто таке, яке виникало не з вини боржника;

2 ) умисне або злісне банкрутство, що виникало, наприклад, через легковажну поведінку покупця (пиятики, розтрати товару або інше) [2, с. 68]. 
Iз цього випливає, що за часів Руської Правди було диференційовано умови застосування відповідальності боржника залежно від причин та виду неоплатності. Так, за випадкового банкрутства, якщо боржником було доведено факт нещасного випадку, внаслідок якого він утратив майно, боржник звільнявся від відповідальності, а саме від виконання зобов'язань. Однак за умисного доведення до банкрутства боржник зобов'язаний був повністю компенсувати нанесену кредиторам майнову шкоду, а в разі його смерті борг повинен бути компенсованим спадкоємцями саме в межах вартості майна.

Продаж боржника 3 метою погашення вимог кредиторів було передбачено й у Статуті Великого князя Володимира Мономаха. Як зазначає на це О.О. Яковлев: «у положеннях Руської Правди простежується подібність із правом Стародавнього Риму, де сама фізична особа, а не тільки ii майно, виступала засобом забезпечення зобов'язань перед кредиторами» [1, с. 147].

Отже, Руська Правда містила положення $з$ регулювання процедури банкрутства, за якими погашення вимог кредиторів могло відбуватись за кошт продажу не тільки майна, але й самого боржника.

Наступний період розвитку інституту банкрутства i, відповідно, продажу майна банкрута, можна пов'язати 3 перебуванням українських земель у складі Російської імперіі. Бурхливий розвиток економічних відносин, який переживала Російська імперія у XVIII ст. (саме в цей період більша частина сучасної України входила до складу Імперіі) викликав необхідність правового врегулювання питань неспроможності й банкрутства. Першою спробою створення кодифікованого акта в цій сфері дослідники називають Статут неспроможності, прийнятий у 1740 р. Цей Статут особливий тим, що в ньому вперше було закріплено статус кураторів як посадових осіб, які обира- лись кредиторами або призначались Комерц-колегією, діяли за дорученням суду та представляли інтереси боржника. До кураторів висувались вимоги щодо сумлінності, виборності лише iз кредиторів п'ятої черги, наявності російського підданства, за винятком ситуацій, коли боржник або будь-хто із кредиторів були іноземцями [3, с. 89]. До того ж дослідники історії розвитку інституту банкрутства зазначають, що фактично Статут 1740 р. не діяв, часто ігнорувався на практиці, що стало поштовхом для розробки нових проєктів «Банкрутських статутів» у 1753, 1763, 1768 роках. Протягом цього часу для ведення справ про неспроможність використовувалось іноземне законодавство, звичаї ділового обороту того часу або видавались окремі укази Сенату у зв'язку з тим, що жоден із проєктів нового «Статуту» за довгий час не набрав чинності.

У 1800 р. було прийнято новий, так званий «Банкрутський статут» (далі «Статут»), який уважається першим у Російській імперії кодифікованим актом про неспроможність. Цей документ уніс передову новелу в законодавство. Фактично «Статут» був поділений на дві частини: про купецьку неспроможність і про взяття дворянами на себе зобов'язань, а також про неспроможність цих осіб [4, с. 90]. Таким чином, уперше у правовій практиці на території сучасної України було введено роздільне регулювання двох видів банкрутства:

1) пов'язане з веденням підприємницької діяльності (історично зване «торговою неспроможністю»);

2) не пов'язане $з$ веденням підприємницької діяльності.

У положеннях «Статуту» законодавець передбачав можливість реструктуризації заборгованості, укладення позасудової мирової угоди із кредиторами, а також надання судом боржникові строку для відновлення платоспроможності. Однак розвиток практики застосування цього «Статуту» й багато колізійних норм привели до необхідно- 
сті системної переробки законодавства про банкрутство.

Черговою сходинкою розвитку інституту банкрутства та продажу майна боржника стало прийняття 25 червня 1832 р. Статуту «Про торгову неспроможність», який був чинним до 1917 p. та застосовувався виключно у випадках торгової неспроможності [5, с. 40]. Як зазначається в літературі, Статут «Про торгову неспроможність» установлював чотири черги кредиторів: церква, борги, забезпечені заставою, заробітна плата працівникам за шість місяців; державні борги, приватні борги; спірні борги, котрі вимагають утручання суду; борги, не пред'явлені у встановлений термін.

Порівняно з попередніми, більш систематизований характер цього Статуту сприяв активному його використанню. Так, за період із 1893 по 1907 рр. в імперії було ліквідовано понад 546 товариств із загальної їх кількості в 1190. Нерідко банкрутами визнавались страхові компанії, металопереробні підприємства [6, с. 10].

Таким чином, можна дійти висновку, що за часів Російської імперії погашення боргів кредиторів відбувалось коштом майна боржника. Продаж майна боржника здійснювався на торгах, також кредитору - заставодержателю - надавалось право залишити нерухоме майно за собою.

Після Жовтневої революції 1917 р. і в перші роки радянської влади конкурсні відносини не могли існувати об'єктивно (за відсутності суб'єктів господарювання). Питання банкрутства i, зокрема, продажу майна банкрута, могли набути актуальності тільки після 1921 р., тобто після запровадження нової економічної політики (НЕП), результатом якої стало відродження вільного товарного обігу. Так, положення щодо банкрутства з'явились у «Цивільному кодексі РРФСР» 1922 р., де було закріплено, котрі суб'єкти цивільного права могли визнаватись банкрутами, які умови та наслідки такого визнання [7]. Проте питання банкрутства не були врегульовані процедурно. Загалом, зазначається, що був відсутній механізм застосування норм цього Кодексу, через що й позитивних зрушень особливо не спостерігалось. Подальше згортання НЕПу й початок у 1928 р. масової колективізації призвело до втрати зазначеними нормами Кодексу практичного значення. За час існування Радянського Союзу нових норм про банкрутство не приймалось.

Важливий етап становлення банкрутства припав на 1990-1991 pp. пісня набуття Україною незалежності. Зокрема, 14 травня 1992 р. було прийнято Закон України «Про банкрутство» № 2343-XII, котрий складався із 22 статей і більше був схожий на збірник тез із вказівками до виконання в разі неспроможності юридичної особи - суб'єкта підприємницької діяльності, пов'язаної з недостатністю активів у ліквідній формі, задовольнити у встановлений для цього строк пред'явлені до нього з боку кредиторів вимоги й виконати зобов'язання перед бюджетом, що, власне, й було визначено ст. 1 як «банкрутство» [9]. Нарешті в цьому Законі було регламентовано продаж майна банкрута шляхом реалізації його на аукціоні. Відповідно до ст. 20 Закону рішення про продаж майна банкрута приймалось ліквідаційною комісією за погодженням зі зборами (комітетом) кредиторів. Голова ліквідаційної комісії забезпечував через засоби масової інформаціï оповіщення про порядок продажу майна банкрута, склад, умови і строки придбання майна. Кошти, виручені від продажу майна банкрута, спрямовувались на задоволення претензій кредиторів. Передусім покривались витрати, пов'язані із провадженням справи про банкрутство в арбітражному суді та роботою ліквідаційної комісіі, функціонуванням розпорядника майна, а також задовольнялись вимоги кредиторів, забезпечені заставою. Подальша черговість кредиторів визначалась згідно зі ст. 20 Закону. 
Закон «Про банкрутство» № 2343XII у першій реакції, звичайно, був далеко не досконалий та мав суттєві недоліки. Він установлював умови та порядок визнання банкрутами для задоволення претензій кредиторів лише такої категорії суб'єктів підприємницької діяльності, як юридичні особи. Цим Законом передбачались тільки дві процедури - санація та ліквідація. За недостатньої врегульованості процедури санації практично основною процедурою ставала ліквідація. Щодо продажу майна банкрута, не врегульованим був механізм продажу - норми мали більш загальний характер. Так, відсутність прикладів успішної реорганізації підприємств, які опинились у скрутному становищі, на думку фахівців із питань банкрутства, свідчила про суттєві прогалини українського законодавства щодо банкрутства [10].

Однак, незважаючи на цілий комплекс недопрацьованих питань, значення цього закону в українському конкурсному праві важко недооцінити. Тоді, коли в молодій державі ще не було прийнято ні власного Цивільного, ні власного Господарського кодексу (в перші місяці після проголошення незалежності основні нормативно-правові акти УРСР було фактично легітимізовано 3 деякими поправками, виснажлива законотворча праця була попереду), менше, ніж через рік після проголошення незалежності України, законодавець прийняв закон, що, хоча б тезово, регулював господарські відносини неплатоспроможного суб'єкта із кредиторами і став основою для повноцінного нормативно-правового акта, яким можна вважати Закон № 2343-XII у своїй 73-й редакції, чинний із 18 січня 2013 p. [11], пройшовши складний шлях удосконалення, набуваючи все більш досконалого вигляду з кожною наступною своєю редакцією.

Так, першої ключової зміни Закон № 2343-XII «Про банкрутство» зазнав у редакції від 30.06.1999 р. (чинний із 1 січня 2000 р.), отримавши, зокрема, нову назву: «Про відновлення плато- спроможності боржника або визнання його банкрутом» та суттево збільшившись в об'ємі, бувши сформованим сімома розділами та 53 статтями [12]. У цій редакції детально визначались терміни, котрі використовувались у Законі, повноваження учасників процесу та державного органу з питань банкрутства, функції арбітражного суду на кожній із процедур, передбачених Законом, вимоги до заяви про порушення у справі про банкрутство, підстави їі прийняття або відмови у прийнятті, вперше введено поняття «мораторію на задоволення вимог кредиторів», уперше застосовано термін «арбітражний керуючий (розпорядник майна, керуючий санацією, ліквідатор)»- фізична особа, яка має ліцензію, видану в установленому законодавством порядку, та діє на підставі ухвали арбітражного суду. Зокрема, Законом досить детально були регламентовані питання продажу у процедурі санації майна боржника як цілісного майнового комплексу, також виокремлений порядок та механізм продажу, а саме у ст. 30 Закону було зазначено, що після проведення інвентаризації та оцінки майна банкрута ліквідатор розпочинає продаж майна банкрута на відкритих торгах. Тобто було запроваджено конкурентний спосіб продажу майна банкрута шляхом проведення аукціонів.

Однак Закон № 2343-XII (чинний із 1 січня 2000 р.) не зазнав фундаментальних змін в умовах та організації продажу майна боржника. У 2011 р. було прийнято нову редакцію Закону України «Про відновлення платоспроможності боржника або визнання його банкрутом, яка містила більш, ніж 20 доповнень та уточнень, що свідчило про низьку ефективність вітчизняного законодавства про банкрутство. Так, 18 січня 2013 р. набрала чинності оновлена редакція Закону, ст. 44 якого стосувалась продажу майна банкрута i якою було передбачено два способи продажу: проведення аукціону та продаж безпосередньо юридичній або фізичній особі. Вибір способів про-

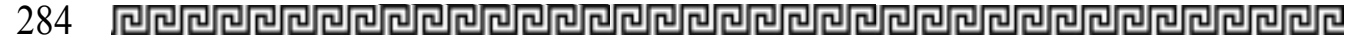


дажу активів здійснювався ліквідатором і був обумовлений обранням ним забезпечення відчуження майна за найвищою ціною.

Такий підхід важко розцінити як цілковито вдалий, оскільки на аукціоні не дуже ефективно продавати малоцінні предмети, які не належать до категоpiï тих, що швидко псуються. Можливим варіантом у такому разі могло бути встановлення цінової межі для продажу майна поза аукціоном. Також Закон містив деякі неузгодження, наприклад, у ч. 1 ст. 49 цього Закону було передбачено, що продаж майна боржника у провадженні у справі про банкрутство здійснюється в порядку, встановленому цим Законом, шляхом проведення торгів у формі аукціону, за винятком майна, продаж якого, відповідно до законодавства України, здійснюється шляхом проведення закритих торгів. Проте ст. 44 передбачала можливість прямого продажу майна боржника фізичним та юридичним особам.

Варто зазначити, що в цій редакції Закону було запроваджено можливість проведення аукціону із продажу майна боржника в електронній формі (ст. 67), що отримало назву електронних торгів. На думку фахівців, така новація у процедурі проведення продажу майна банкрута дозволяє не тільки потенційним учасникам електронних торгів заощадити час на участь у торгах, пошук інформації щодо майна, котре пропонується до продажу, але і стимулюватиме продаж майна за найвищою ціною [13].

У редакції Закону 2013 р. доступ до місця проведення аукціону регламентувався ст. 63, якою було передбачено, що організатор забезпечує доступ до місця проведення аукціону учасникам аукціону, замовнику аукціону та особам, указаним замовником, працівникам державних органів під час виконання іхніх службових обов'язків та представникам засобів масової інформації. Для участі в такому аукціоні покупці одержують квитки учасників аукціону, які повинні містити відомості про таке: назву майна, в аукціоні якого бере участь покупець, умови проведення аукціону. Однак така процедура не була розрахована на випадки проведення аукціону в електронній формі. Так, у правилах проведення електронних торгів переважно визначається, що брати участь в аукціоні мають право виключно зареєстровані учасники, які отримали індивідуальний код учасника. Зі свого боку, учасниками визнаються особи, які $€$ зареєстрованими користувачами електронної торгової системи, сплатили реєстраційний та/або гарантійний внесок, пройшли процедуру реєстраціі, отримали відповідне підтвердження про реєстрацію учасника торгів та індивідуальний код учасника [14; 15].

Отже, від першої редакції Закону України «Про банкрутство» й до прийняття Кодексу із процедур банкрутства в Україні способом продажу майна банкрута спочатку був продаж майна на аукціоні, додався продаж безпосередньо фізичній або юридичній особі, а 3 кінця 2013 р. запроваджено можливість проведення аукціону із продажу майна боржника в електронній формі.

Наразі Україна перебуває в турбулентному становищі та відчуває значні зміни в законодавстві. Реформування торкнулось і сфери банкрутства. Так, 21 жовтня 2019 р. набув чинності новий Кодекс із процедур банкрутства. Із цієї ж дати припинив дію Закон України «Про відновлення платоспроможності боржника або визнання його банкрутом». Зазначений вище Кодекс запроваджує продаж майна боржників виключно на аукціоні в електронній системі, відмовившись від інших способів продажу майна та форм проведення аукціонів [16]. Реалізація майна боржника є заключним етапом процедури банкрутства й від належного іii унормування безпосередньо залежить факт задоволення майнових вимог його кредиторів максимально ефективним чином. Тому вдосконалення відповідних положень законодавства $є$ важливим етапом загального процесу реформування законодавства про банкрутство. 
Щодо продажу майна банкрута, положеннями Кодексу вперше детально визначено поняття авторизованих електронних майданчиків, регламентуються організація i проведення аукціону, умови участі в аукціоні, регулюються відносини між замовником аукціону та учасниками, встановлено відповідальність перед особами, які не змогли взяти участь або перемогти на аукціоні, уточнено особливості проведення аукціону із продажу права вимоги та багато іншого.

Фіналізуючи викладене, можна дійти висновку, що Кодекс позиціонується як прокредиторський, у тому сенсі, що процедури банкрутства передбачають швидкісний підхід до реалізації майна боржника та максимальне задоволення фінансових вимог кредитора, вектор регулювання відносин неплатоспроможності спрямовано на пріоритетний захист інтересів кредитора. Це відповідає заявленим цілям щодо підвищення позиції України в рейтингу Doing Business, що є досить важливим кроком у розвитку нашої країни.

Таким чином, можна зробити висновок, що норми про продаж майна банкрута є невід'ємним складником законодавства про банкрутство, у становленні й розвитку якого можна виділити такі основні етапи: етап Київської Русі, етап знаходження українських земель у складі Російської імперії, етап існування УРСР та новітній етап, який розпочався після набуття Україною незалежності, протягом яких нормами права закріплювались способи задоволення вимог кредиторів та способи продажу майна банкрута, положення щодо організації та здійснення продажу майна.

Кожний історичний етап розвитку законодавства в цій сфері вирізняється своїми способами задоволення вимог кредиторів та способами продажу майна банкрута, починаючи 3 часів Руської правди (погашення вимог кредиторів могло відбуватись за кошт продажу майна та самого боржника), й до періоду продажу майна боржника в електронній формі, шляхом проведення електронних торгів.

У статті розглянуто історичний розвиток та становлення інституту банкрутства в аспекті продажу майна боржника. У процесі дослідження з’ясовано, шо виникнення кредитних відносин дало значний поштовх у зародженні інституту неспроможності, в якому головними дійовими особами були кредитор та боржник.

Початковим етапом розвитку законодавства про банкрутство виступає період Киїської Pусі та діï Руської правди, в положеннях якої було диференційовано умови застосування відповідальності боржника залежно від причин та виду неоплатності. Так, за випадкового банкрутству й доведенні факту нещасного випадку боржник звільнявся від відповідальності, а саме від виконання зобов'язань. У цей час погашення вимог кредиторів могло відбуватись за кошт продажу майна та самого боржника. Наступним етапом визначено період Російської Імперії. Для регулювання відносин банкрутства було прийнято декілька Статутів, останній із яких прийнято в 1800 p. i який вважався першим у Російській імперії кодифікованим актом про неспроможність. Ним уперше було введено роздільне регулювання двох видів банкрутства: 1) пов'язане з веденням підприємницької діяльності (історично зване «торговою неспроможністю»); 2) не пов'язане з веденням підприємницької діяльності. Зазначено, що найважливіший етап становлення інституту банкрутства віббувся після набуття Україною незалежності, від прийняття та вдосконалення Закону України «Про банкрутство», положеннями якого встановлювались та змінювались способи продажу майна банкрута.

На основі проведеного дослідження зроблено висновок, що норми про продаж майна банкрута є невід’єм- 
ним складником законодавства про банкрутство, у становленні й розвитку якого можна виділити такі основні етапи: eman Kиївської Pусі, етап перебування українських земель y складі Російської імперї, eman існування УРСР та новітній етап, котрий розпочався після набуття Україною незалежності, протягом яких нормами права закріплювались способи задоволення вимог кредиторів та способи продажу майна банкрута, положення щзодо організації та здійснення продажу майна.

Ключові слова: банкрутство, майно боржника, продаж майна, аукціон, електроні торги.

Tyurina Yu. Formation and development of legislation on the sale of bankrupt property

The article describes the historical development and formation of Institute of bankruptcy in the aspect of sale of property of the debtor. The study found that the emergence of credit relations gave a significant impetus to the emergence of the institution of insolvency, in which the protagonists were the creditor and the debtor.

The initial stage of development of bankruptcy law is the period of Kievan Rus and the actions of Russian truth, the provisions of which was differentiated terms of application of the liability of the debtor, depending on the reason and type of Neoplatonist. So, in case of accidental bankruptcy and the proof of the fact of the accident, the debtor is released from responsibility, from commitment. This time of repayment of requirements of creditors could be due to the sale of the property and the debtor itself. The next step determined the period of the Russian Empire. For the regulation of bankruptcy has enacted several Statutes, the last of which passed in 1800, which was considered the first in the Russian Empire, codified by the act of insolvency. It was first introduced separate regulation of the two types of bankruptcy: 1) related business activities (historically called "commercial insolvency");2) not related to entrepreneurial activities. Identified as a crucial stage in the formation of the institution of bankruptcy took place after Ukraine gained independence from the adoption and improvement of the law of Ukraine "On bankruptcy", the provisions of which were established and changed methods of sale of property of the bankrupt.

On the basis of the conducted research the conclusion is made that the rules on the sale of the bankrupt's property is an integral part of bankruptcy laws, in the formation and development of which it is possible to allocate following basic stages: the stage of Kievan Rus, the stage presence of the Ukrainian lands in the Russian Empire, the stage of existence of the USSR and the latest phase, which began after Ukraine gained independence, during which the law has established ways to meet the claims of creditors and the methods of sale of property of the bankrupt, the situation on the organization and implementation of the sale of the property.

Key words: bankruptcy, debtor's property, sale of property, auction, electronic bidding.

\section{Література}

1. Яковлев О.О. Становлення та історичні етапи розвитку інституту банкрутства в Україні. Університетські наукові записки. 2010. № 2. С. 140-148.

2. Российское законодательство X-ХХ веков. В девяти томах. T. 1. Законодательство Древней Руси. / Ю. Г. Алексеев, В. М. Клеандрова, Т. Е. Новицкая и др.; под общей редакциий О.И. Чистякова. Москва: Юридическая литература. 1984. 432 c. URL: https://istina.msu.ru/ publications / book/16533008/.

3. Поляков Б.М. Давньоруський конкурсний процес. Санація та банкрутство. 2006. № 1. C. 89 URL: http: / / www.library.univ. kiev.ua/ukr/elcat/new/detail.php3?doc_ $i d=1170593$.

4. Поляков Б.М. Конкурсний процес царської Росії. Санація та банкрутство. 2006. № 1. C. 90-91. URL: http:// 


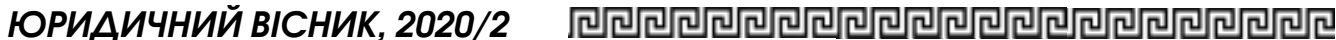

www.library.univ.kiev.ua/ukr/elcat/ new/ detail.php3?doc_id=1170593.

5. Экономическое (коммерческое) правосудие в России: Зарождение и развитие коммерческого правосудия (ХІІ-ХІХ вв.) в 4 m. Т. 1 / Г.Ю. Семигин, В.Ф. Яковлев; отв. ред. Л.Н. Алисова. Москва: Moıcль, 2004. URL: http: / /lawlibrary.ru/ izdanie52517.html.

6. Чабан Ю.М. Історія становлення i розвитку інституту неспроможності (банкрутства) в Україні. Юридична Україна. 2004. № 6. C. 44-48.

7. Мельник Т.П. Становление российского законодательства о несостоятельности (банкротстве) в XX веке. Пространство экономики. 2008. № 2-2. URL: https://cyberleninka.ru/article/n/ stanovlenie-rossiyskogo-zakonodatelstva$o$-nesostoyatelnosti-bankrotstve-v-xx-veke (дата обращения: 04.06.2020).

8. Капустін B.В. Банкрутство: генезис, сутність $i$ поняття в умовах сьогодення. Порівняльно-аналітичне право. 2013 р. № 3-2. C. 165-168. URL: http:// wrw.pap.in.ua/3-2_2013/47.pdf.

9. Про банкрутство: Закон України від 14 травня 1992 р. № 2343-ХII. Законодавство України. URL: http://zakon1.rada.gov.ua/ laws/show/2343-12.

10. Винниченко Ю.В. Історичне становлення правових основ регулювання банкрутства. URL: http:// bezdolgov.info/publ/nauchnyestati/ istoricheskoe_stanovlenie_pravovykh_osnov_ regulirovanija_bankrotstva/1-1-0-3.

11. Про відновлення платоспроможності боржника або визнання його банкрутом: Закон України в редакиії від 18 січня 2013 р. № 2343-ХII. Законодавство України. URL: http://zakon1.rada.gov.ua/ laws / show / 2343-12.

12. Про відновлення платоспроможності боржника або визнанні його банкрутом: Закон України в редакції від 30 червня 1999 р. № 784. Відомості Верховної Ради України. 1999. № 42-43. Ст. 378.

13. Маковій B.I. Електронні торги не панацея від усіх бід. Cайm: «Банкрутство \& Ліквідація». 2015. 30 вересня. URL: http: / / bankruptcy-ua.com / articles / 2030.

14. Правила проведення аукціону у формі електронних торгів в проиедурах банкрутства TOB «Професіонал». URL: https: / / www.aykcion.com.ua/ normativnabaza/pravila-provedennia-vidkritikhelektronnikh-torgiv.

15. Правила проведення електронних торгів. Сайт Першої Украӥнськоӥ Міжрегіональної Товарної Біржі. URL: https:// www.pumtb.com.ua/normativna-baza/ pravila-provedennia-vidkritikh-elektronnikhtorgiv.

16. Кодекс України з процедур банкрутства: Закон України від 18 жовтня 2018 р. № 2597-VIII. Законодавство Українu. URL: https://zakon.rada.gov.ua/ laws / show / 2597-19 